\title{
Interleukin-13 Receptor Subunit Alpha-2
}

National Cancer Institute

\section{Source}

National Cancer Institute. Interleukin-13 Receptor Subunit Alpha-2. NCI Thesaurus. Code C105975.

Interleukin-13 receptor subunit alpha-2 (380 aa, $\sim 44 \mathrm{kDa}$ ) is encoded by the human IL13RA2 gene. This protein plays a role in both B-cell differentiation and maturation. 